\title{
Critical Particulate Contaminant(s) Generated during Arc Welding on Aluminum Alloys
}

\author{
Thomas Neil McManus ${ }^{1,2} \&$ Assed N. Haddad ${ }^{3}$ \\ ${ }^{1}$ NorthWest Occupational Health \& Safety, North Vancouver, Canada \\ ${ }^{2}$ Programa de Engenharia Ambiental, Universidade Federal do Rio de Janeiro, Rio de Janeiro, Brazil \\ ${ }^{3}$ Escola Politécnica, Universidade Federal do Rio de Janeiro, Rio de Janeiro, Brazil \\ Correspondence: Thomas Neil McManus, NorthWest Occupational Health \& Safety, North Vancouver, BC., \\ V7K1P3, Canada. E-mail: nwohs@mdica
}

Received: December 31, 2019

Accepted: January 17, $2020 \quad$ Online Published: January 24, 2020

doi:10.5539/enrr.v10n1p43

URL: https://doi.org/10.5539/enrr.v10n1p43

\begin{abstract}
Assessing exposure to particulate emissions during arc welding is an important consideration in assuring compliance with regulatory requirements. This study examined welding emissions during argon-shielded GMAW (MIG welding) processes involving aluminum alloys in a shipbuilding environment using traditional methods of air sampling (portable pumps and closed-face cassettes containing PVC filters.) Current requirements for exposure determination (inhalable, respirable and total particulates) necessitate three simultaneous samples, a very onerous imposition on worker safety and comfort. Application of a conversion factor published in the literature can considerably simplify this situation through use of a single sampler, the conventional closed face cassette. This approach provides a first-level means of evaluation and is especially useful where exposure levels are low compared to regulatory Exposure Limits. Assessment of exposure to chromium, magnesium and manganese may require additional consideration because of the necessity for simultaneous evaluation against TLVs for inhalable and respirable particulates and different oxidation states. Results strongly suggest that beryllium and/or chromium VI and possibly manganese dominate consideration about exposure and control measures (Critical Particulate Contaminant). This results from the difficulty of analysis created by the combination of extremely small Exposure Limits, presence of these elements in the alloy in trace to very small quantities and uncertainty associated with detectability in standard air samples. Resolving this question requires collection and analysis of bulk quantities of welding fume to improve the mathematics associated with detectability. Determination of the Critical Particulate Contaminant considerably simplifies future evaluation and focuses follow-up action in the appropriate direction.
\end{abstract}

Keywords: Air Sampling, Aluminum Alloy, Critical Particulate Contaminant, Fume, GMAW Process

\section{Introduction}

\subsection{Arc Welding on Aluminum Alloys}

Fabrication of structures from aluminum alloys involving gas-shielded, arc welding and associated metalworking activities in a shipbuilding environment is a complex undertaking. Technical journals offer little discussion about the health and safety aspects of gas-shielded, arc welding on aluminum alloys and how to address them in a strategic manner. By contrast, stainless steel, another 'polished metal', has received considerably greater attention because of concern about exposure to nickel and chromium VI. Unusual fatigue (McManus \& Haddad, 2015b) reported by welders performing argon-shielded GMAW (Gas Metal Arc Welding also known as Metal Inert Gas (MIG) welding) prompted the investigation partly reported in this article. This fatigue did not affect welders working on carbon steel in the same shipyard.

\subsection{Industrial Hygiene of Arc Welding on Aluminum Alloys}

This article is one of a series concerning the industrial hygiene aspects of argon-shielded arc welding on aluminium alloys (McManus \& Haddad, 2013; McManus \& Haddad, 2014; McManus \& Haddad, 2015a; McManus \& Haddad, 2015b; McManus \& Haddad, 2016; McManus \& Haddad, 2018; McManus \& Haddad, 2019a; McManus \& Haddad, 2019b; McManus \& Haddad, 2020). These articles reported on ultra-violet emissions (McManus \& Haddad, 2013); use of methanol as a coolant/lubricant during milling (McManus \& Haddad, 2014); oxygen levels during arc welding (McManus \& Haddad, 2015a); argon-related fatigue (McManus \& Haddad, 
2015b); formation of CrVI from chromium in the aluminum alloy (McManus \& Haddad, 2016); methodology for measuring exposure to $\mathrm{NO}$ and $\mathrm{NO}_{2}$ and welder exposure to $\mathrm{NO}_{2}$ (McManus \& Haddad, 2018; McManus \& Haddad, 2019a) and methodology for measuring exposure to ozone and welder exposure to ozone (McManus \& Haddad, 2019b; McManus \& Haddad, 2020).

\subsection{Air Sampling for Particulates during GMAW (MIG Welding) on Aluminum Alloys}

This article reports on investigation of particulate emissions during welding on 5000 and 6000 series aluminium alloys used in fabrication of large ship structures (Table 1). Most of the arc welding that occurred during this project involved argon-shielded, Gas Metal Arc Welding (GMAW) also known as Metal Inert Gas (MIG) welding.

Table 1. Major elemental composition of 5000 and 6000 series aluminum alloys.

\begin{tabular}{llllllllll}
\hline \multirow{2}{*}{ Alloy } & \multicolumn{2}{l}{ Element (\%) } & \multicolumn{1}{l}{$\mathrm{Mg}$} & $\mathrm{Cr}$ & $\mathrm{Zn}$ & $\mathrm{Ti}$ & $\mathrm{Al}$ \\
\cline { 2 - 10 } & $\mathrm{Si}$ & $\mathrm{Fe}$ & $\mathrm{Cu}$ & $\mathrm{Mn}$ & $\mathrm{Mg}$ & \\
\hline 5052 & 0.25 & 0.4 & 0.10 & 0.10 & $2.2-2.8$ & $0.15-0.35$ & 0.10 & & remainder \\
5083 & 0.40 & 0.4 & 0.10 & $0.40-1.0$ & $4.0-4.9$ & $0.05-0.25$ & 0.25 & 0.15 & remainder \\
5086 & 0.40 & 0.5 & 0.10 & $0.20-0.7$ & $3.5-4.5$ & $0.05-0.25$ & 0.25 & 0.15 & remainder \\
6061 & $0.40-0.8$ & 0.7 & $0.15-0.40$ & 0.15 & $0.8-1.2$ & $0.04-0.35$ & 0.25 & 0.15 & remainder \\
6063 & $0.20-0.6$ & 0.35 & 0.10 & 0.10 & $0.45-0.9$ & 0.10 & 0.10 & 0.10 & remainder \\
6066 & $0.9-1.8$ & 0.5 & $0.7-1.2$ & $0.6-1.1$ & $0.8-1.4$ & 0.40 & 0.25 & 0.20 & remainder \\
\hline
\end{tabular}

Adapted from Altenpohl, 1982; Davis, 1993; Hatch, 1984; Mondalfo, 1976.

Welding and associated metalworking activities in the aluminum shipbuilding environment are discontinuous in time and space. Welding often occurs in short bursts and in different geometries and locations. Aluminum alloys contain many elements whose concentrations range from part per million ( $\mathrm{ppm}$ ) to percent levels (Altenpohl, 1982; Davis, 1993; Hatch, 1984; Mondalfo, 1976).

Product specification sheets provided by manufacturers often provide information about trace elements. Components are added in precisely measured quantities. Sodium, potassium, calcium, lead, and strontium generally are not present in these alloys. Beryllium, cadmium, lead, and nickel not always disclosed in product specification sheets may be present as contaminants or elements accompanying major elements (Altenpohl, 1982; Davis, 1993; Hatch, 1984; Mondalfo, 1976). Beryllium also is an additive in some aluminum alloys. To illustrate, aluminum alloy, A357.0, contains $0.040 \%$ to $0.070 \%$ beryllium (Frede, 2010 ) and other alloys contain $10 \%$ to $75 \%$ (Hashiguchi et al., 2018).

The air in an aluminum shipbuilding environment contains both gaseous and particulate contaminants (NIOSH, 1988). The particulate contaminants originate from various sources. These include the welding fume contained in the welding plume, fine fragments of metallic aluminum produced by metalworking and aerosols contained in outdoor air. Arc welding involves input of considerable electrical energy. The electric arc liquefies the base metal and the consumable metal in the electrode (wire). Emission of metal atoms occurs from the pool of liquid into the gaseous shield space and then into the atmosphere. The atoms react with oxygen in the atmosphere outside the gaseous shield and with ozone created from interaction between ultra-violet (UV) emissions from the arc and oxygen to produce metallic oxides (McKinley, 1992; NIOSH, 1988). As a result, unreacted metal atoms are unlikely to be present in particulate material produced during arc welding unless ejected as bulk material in spatter. The metallic oxides form clusters and chains.

Metalworking activity associated with arc welding inside large ship structures on surfaces later to become inaccessible includes primarily milling of metal surfaces and very little abrasion. Milling involves routers for machining edges and grinders containing carbide-tipped blades for gouging metal from flat surfaces and corners. Airborne fragments and particles of metal generated during milling fall rapidly to horizontal surfaces. Inhalation of fragments and particles of this size is very unlikely.

Evaluation of exposure from welding is more difficult than from other processes because of the generation of many air contaminants including both gaseous and particulate. McManus and Haddad (2018) have shown that $\mathrm{NO}_{2}$ is a Critical Gaseous Contaminant during Gas Tungsten Arc Welding (GTAW) [Tungsten Inert Gas (TIG) welding]. Similarly, ozone is a Critical Gaseous Contaminant during GMAW (MIG welding) (McManus \& Haddad. 2019b). Critical Contaminants have the potential to exceed regulatory Exposure Limits leading to overexposure of welders and obligation of corrective action by regulatory requirements. Typically, in any process, one air contaminant will 
dominate exposure assessment and the need to implement control methods. Following identification of the Critical Contaminant, surveillance of exposure and control efforts can focus on that substance in the knowledge that control of exposure to the other substances will also occur.

The published literature contains no information for developing a strategy to enable efficient and cost-effective evaluation of conditions. Elements identified in Table 1 provide a starting point for approaching this problem. Many jurisdictions use the Threshold Limit Values (TLVs) published by the American Conference of Governmental Industrial Hygienists as Regulatory Exposure Limits (ACGIH, 2018). TLVs exist for most but not all of the elements mentioned in Table 1. In the case of silicon ( $\mathrm{Si}$ ), TLVs exist for oxides (forms of silica) and not for the element.

TLVs for particulates currently are expressed in different ways (total particulates, respirable particulates, and inhalable particulates). The type of the TLV dictates the type of collection device required for air sampling (SKC, 2018). Total particulates are particles collected using a portable pump operated at a flow rate typically around 2 $\mathrm{L} / \mathrm{min}$ and an open- or closed-face cassette containing a $37 \mathrm{~mm}$ microporous filter. Respirable sampling can involve the same or a different type of cassette and filter in a sampling train containing a cyclone, operated typically at $1.7 \mathrm{~L} / \mathrm{min}$. The cyclone removes particles larger than $10 \mu \mathrm{m}$ in diameter from the airstream according to a defined profile. The surface of the filter collects particles smaller than $10 \mu \mathrm{m}$ in diameter. Inhalable samplers operate at flow rates ranging from 2 to $4 \mathrm{~L} /$ min that depend on the sampling device.

Current discussion about sampling during arc welding in on-line forums indicates that practitioners are realizing that this situation poses considerable logistical issues. To illustrate, a separate sampling device is required for each type of TLV. TLVs involved in welding require 3 types of sampling device. Simultaneous sampling to obtain values that correspond directly to each other during a particular day and set of conditions is absolutely essential in order to enable comparison. Statistical reliability requires at least 6 samples per device (Jahn et al., 2015). This means that a sampling campaign to evaluate worker exposure during arc welding on aluminium alloys could require at least 18 samples.

Use of multiple sampling devices also poses serious safety issues. These concerns reflect the fact that individual metals can have several TLVs, each requiring a different sampling device and sampling pump (Figure 1 and Figure 2). Sampling using up to 3 pumps and devices per person is cumbersome and not likely to be tolerated. Furthermore, the position of the sample devices on the lapel can pose serious a safety risk because of the potential to interfere with protection provided by the welding helmet. The welding helmet must fully close to offer full protection to the welder. In addition, sampling devices exposed on the lapel are subject to damage and destruction. Complicating sampling still further, Goller and Paik (1985) showed that there is potential for between sampler differences even when operated simultaneously on the torso of a welder. Samples obtained in various positions outside the welding helmet overestimated the concentration of welding fume compared to that inside by a factor of 1.4. That is, the concentration of welding fume obtained outside the welding helmet was about 1.4x higher than what the welder was capable of inhaling.

Previous discussion indicated that minimizing the number of samplers is an important part of the sampling strategy especially in the hazardous conditions posed by the welding environment. That is, can a measurement from one type of sampler provide sufficient information to enable assessment against more than one type of TLV? Werner et al. (1996) in simultaneous measurements of the type described above demonstrated quantitative relationships between different samplers in the same circumstances. Reference to this work has occurred in presentations and additional peer-reviewed articles (Spear, 2015; Vincent et al., 1997). Relevant to this discussion, these authors derived a conversion factor of 1.0 (respirable to total) for air samples obtained during welding and 2.5 for samples generated by dusty operations (inhalable to total). That is, to predict the concentration obtainable by inhalable sampling or respirable sampling, multiply the concentration obtained by closed face sampling for total particulates by the conversion factor applicable to the particular type of work. The context of the operation determines applicability of the conversion factor. Where the sample contains only welding fume, all of the particulates are present in respirable form. In this case, the concentration of total particulates is the same as the concentration of respirable particulates. This approach provides a strategy for first-level approximation for comparison against TLVs through a single method for collecting samples and for focussing attention on Critical Particulate Contaminant(s). 
Table 2. Metals Provided in ICP Analysis and Relevant Exposure Limits

\begin{tabular}{|c|c|c|}
\hline Metal & SDS & $\operatorname{TLV-TWA}\left(\mu \mathrm{g} / \mathrm{m}^{3}\right)$ \\
\hline - Aluminum, metal and insoluble compounds & Yes & 1000, respirable \\
\hline - Barium and soluble compounds, as Ba & No & 500 \\
\hline \multirow[t]{2}{*}{ - Beryllium and compounds, as $\mathrm{Be}$} & Yes & 2 \\
\hline & & 0.2 (OSHA, 2018) \\
\hline \multirow[t]{2}{*}{ - Cadmium and compounds, as $\mathrm{Cd}$} & No & $10, \mathrm{~A} 2$ \\
\hline & & 2 , respirable, $\mathrm{A} 2$ \\
\hline - Calcium & No & \\
\hline oxide, as $\mathrm{Ca}$ & & 2000 \\
\hline chromate, as $\mathrm{Cr}$ & & $1, \mathrm{~A} 2$ \\
\hline - Chromium and inorganic compounds, as $\mathrm{Cr}$ & Yes & \\
\hline metal and CrIII compounds & & $500, \mathrm{~A} 4$ \\
\hline water-soluble CrVI compounds & & $25, \mathrm{~A} 1$ \\
\hline insoluble CrVI compounds & & $10, \mathrm{~A} 1$ \\
\hline hexavalent chromium & & 5 (OSHA, 2015) \\
\hline - Cobalt and inorganic compounds, as Co & No & $20, \mathrm{~A} 3$ \\
\hline - Copper, as $\mathrm{Cu}$ & Yes & \\
\hline fume & & 200 \\
\hline dusts and mists & & 1000 \\
\hline - Iron oxide dust and fume, as $\mathrm{Fe}$ & Yes & 5000, respirable, A4 \\
\hline \multicolumn{3}{|l|}{$\cdot$ Lead } \\
\hline metal and inorganic compounds, as $\mathrm{Pb}$ & No & 50 \\
\hline chromate, as $\mathrm{Cr}$ & No & $12, \mathrm{~A} 2$ \\
\hline • Magnesium oxide, fume, as $\mathrm{Mg}$ & Yes & 10,000 , inhalable, $\mathrm{A} 4$ \\
\hline \multirow[t]{2}{*}{ - Manganese, elemental and inorganic compounds, as Mn } & Yes & 20, respirable, A4 \\
\hline & & 100 , inhalable \\
\hline \multirow[t]{2}{*}{ - Molybdenum, metal and insoluble compounds, as Mo } & No & 10,000 , inhalable \\
\hline & & 3000 , respirable \\
\hline - Nickel, as Ni & Yes & \\
\hline elemental & & 1500 , inhalable, A5 \\
\hline soluble inorganic compounds, as $\mathrm{Ni}$ & & 100 , inhalable, A4 \\
\hline insoluble inorganic compounds, as $\mathrm{Ni}$ & & 200, inhalable, A1 \\
\hline Potassium & No & No TLV \\
\hline Silver, metal, dust and fume & No & 100 \\
\hline Sodium & No & No TLV \\
\hline Strontium, strontium chromate, as $\mathrm{Cr}$ & No & $0.5, \mathrm{~A} 2$ \\
\hline Tin, metal, oxide, andinorganic compounds, as $\mathrm{Sn}$ & No & 2000 \\
\hline Tungsten, metal and insoluble compounds, as W & No & 5000 \\
\hline - Vanadium, pentoxide, as $\mathrm{V}$ & No & 50 , inhalable, $\mathrm{A} 3$ \\
\hline$\cdot$ Zinc & Yes & \\
\hline chromate, as $\mathrm{Cr}$ & & $10, \mathrm{~A} 1$ \\
\hline oxide & & 2000, respirable \\
\hline Zirconium, metal and compounds, as $\mathrm{Zr}$ & No & 5000 \\
\hline
\end{tabular}

Notes: A1 means confirmed cause of cancer in humans based on epidemiological evidence. A2 means suspected human carcinogen. A3 means confirmed animal carcinogen with unknown relevance to humans. A4 means not classifiable as a human carcinogen. A5 means not suspected as a human carcinogen. (SEN) means sensitization. Skin means danger of absorption through the skin (ACGIH, 2018). 


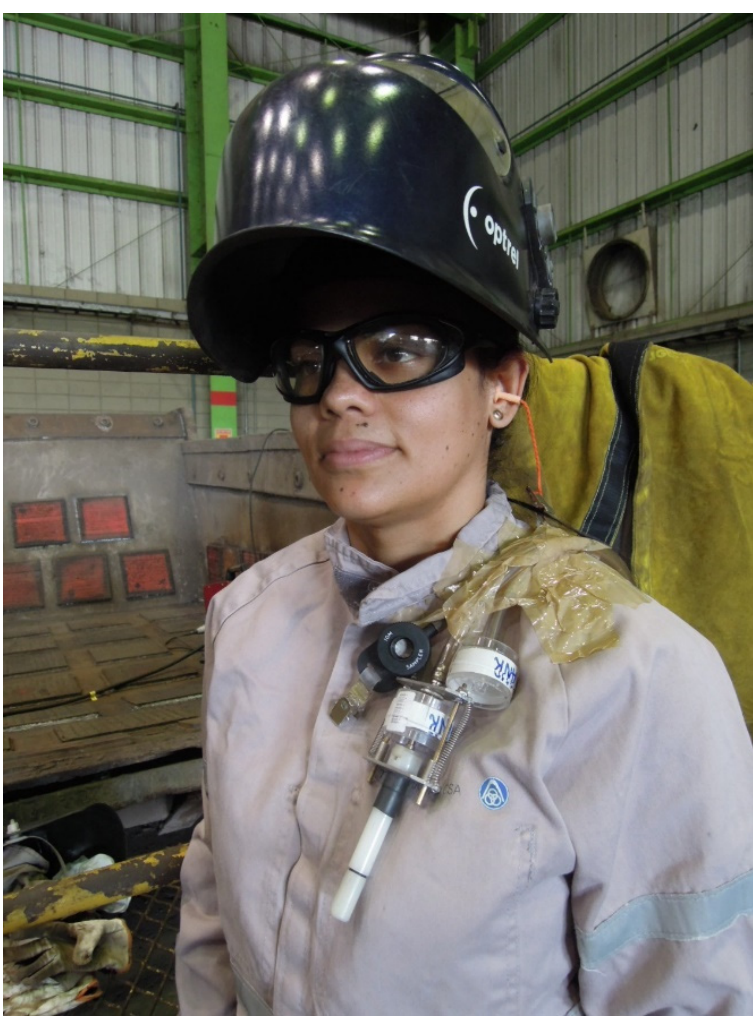

Figure 1. Front view showing devices for particulate sampling during welding. The cyclone must remain vertical during sampling

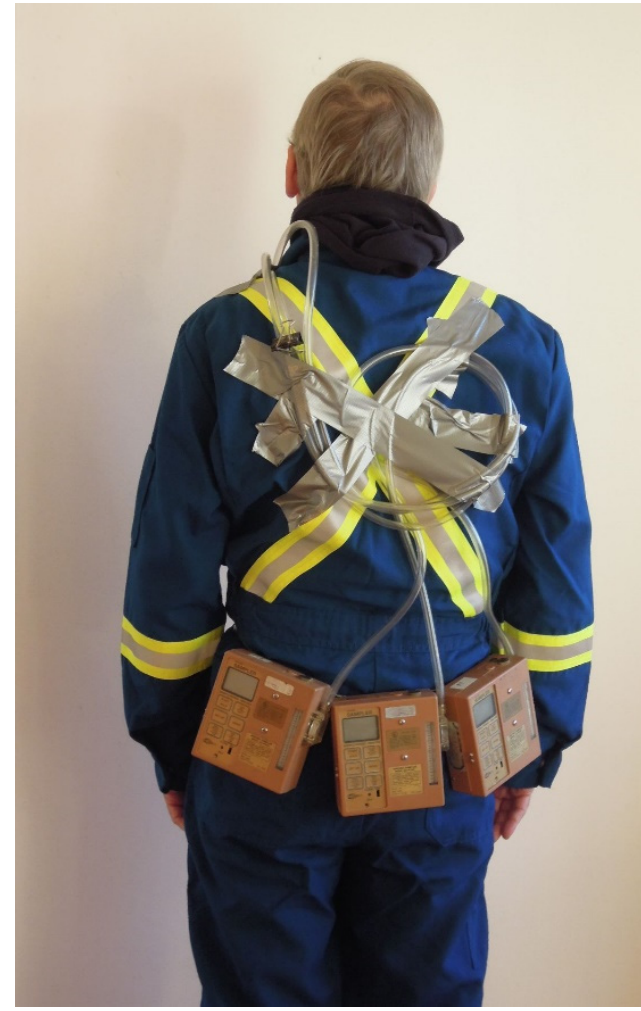

Figure 2. Rear view showing sampling pumps and associated tubing. This equipment is bulky, heavy, and reduces mobility

Another consideration is the information obtainable from analysis for metals in the particulate material collected in an air sample. Analysis for specific individual elements is possible as well as broad-spectrum analysis. Inductively Coupled Plasma (ICP) provides concentrations for many elements in a single analysis (Schlecht \& O'Connor 2003). Analysis for at least 35 elements is easily achievable.

Regulatory Exposure Limits vary considerably for individual elements present in the alloy (ACGIH, 2018). Table 2 lists the metals provided in the analytical report and TLVs potentially applicable to this situation (welding fume and airborne particulates). The TLVs provided in Table 2 also apply to the chemical forms in which these elements could be present in fume from welding and dust from grinding. The TLVs provided in Table 2 apply over an 8-hour workshift. OSHA in the US enforces $5 \mu \mathrm{g} / \mathrm{m}^{3}$ as the regulatory Exposure Limit for hexavalent chromium averaged over 8 hours (OSHA, 2015) and $0.2 \mu \mathrm{g} / \mathrm{m}^{3}$ for beryllium (OSHA, 2018).

The column under SDS (Safety Data Sheet) indicates elements identified by the manufacturers as being present in the alloys in plate, wire and extrusions.

Considerable difficulty arises when the analytical report indicates an element to be present at less than the limit of detection (Armbruster \& Pry, 2008; Jahn et al., 2015). This concern applies most particularly to elements present in trace quantities having very low TLVs, in particular beryllium and chromium (ACGIH, 2018; OSHA, 2015; OSHA, 2018). Uncertainty in the analysis expressed through the ' $<$ 'sign raises two possibilities: first, that the element was present but not able to be reported quantitatively and second, that the element was not present and therefore, not able to be detected. The analytical report normally does not distinguish between these possibilities. The only way to resolve the question is to analyze a large quantity of metal or welding fume in order to overpower the concern expressed by the ' $<$ ' symbol. When substances are known or suspected to be present but not detected, for example, beryllium, the limit of detection accompanied by the ' $<$ ' symbol is used in calculations that follow. The analyst is compelled to use this value in the calculations. Using this value could overstate the concentration that is actually present to the point of creating the false impression of an overexposure. While this approach would provide a highly conservative approach to assessing potential exposure, a better strategy is to collect considerably more material than present on the surface of a filter. The methodology of McManus and Haddad (2016) offers the means to perform this determination under actual conditions of operation. 
ICP analysis provides the benefit of detecting elements whose presence was not known or suspected through absence of disclosure. The benefits provided by this approach outweigh the inconvenience associated with the issue of non-detectability. However, accepting as present elements that are undetectable by the analysis just because the instrument 'looks for them' and for which there is no other evidence is potentially counterproductive.

\section{Method}

Air samples were collected using pumps similar to those shown in Figure 2 (SKC Inc., Eighty Four, PA) and matched-weight PVC (polyvinylchloride) filters held in closed-face, plastic cassettes (total particulates). Pumps were calibrated before and after use. Samplers were positioned in the breathing zone on the chest below the shoulder. This position enabled sampling regardless of the type of respirator in use. The A2 machine operator wore the sampling pump.

CSA-CWB W47.2 Aluminum (CSA Group, 2011) was followed during this work. The A2 machine (ESAB, Mississauga, $\mathrm{ON}$ ) is an automated unit used for welding long seams on horizontal surfaces (Figure 3). Table 3 provides additional information concerning welding conditions (Swint, 2015). Note that the welding wire, ER-5183 is an alloy of aluminium in the same series as the base metal and contains no flux.

Table 3. Welding parameters during sampling for particulates

\begin{tabular}{lll}
\hline Parameter & Current (Amperes) & Voltage (Volts) \\
\hline GMAW (MIG) production welding. & & \\
• horizontal fillet weld (5083 base material, ER-5183 wire, $1.2 \mathrm{~mm}$ diameter) & 190 to 240 & 24 to 25 \\
• vertical up fillet weld (5083 base material, ER-5183 wire, $1.2 \mathrm{~mm}$ diameter) & 160 to 190 & 24 to 25 \\
• overhead fillet weld (5083 base material, ER-5183 wire, $1.2 \mathrm{~mm}$ diameter) & 180 to 220 & 24 to 25 \\
\hline
\end{tabular}

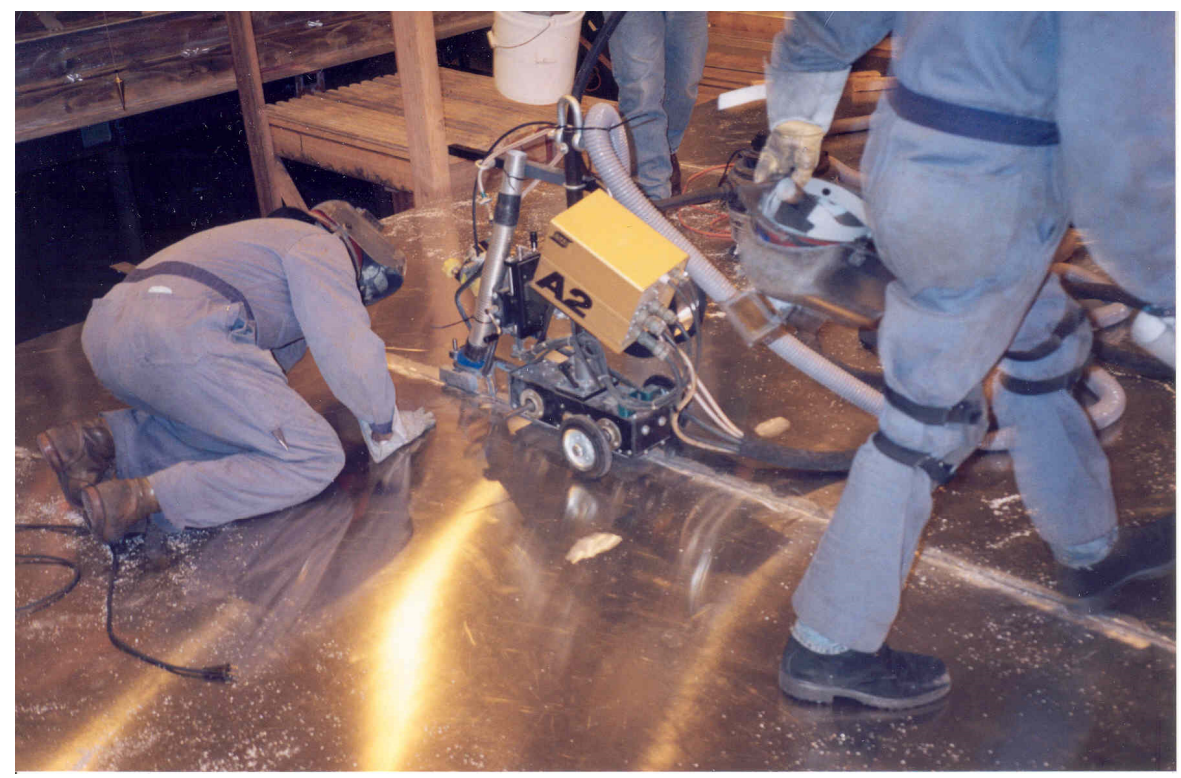

Figure 3. A2 welding machine. During operation, the operator observed the arc and progression of the weld from close proximity

The filters were weighed separately and the mass of material was determined by subtraction of the unloaded filter from the loaded one. A selection of filters from the group believed to have received the highest level of exposure was submitted for ICP analysis. In this circumstance, there was no reason to believe that analysis of a broader group or the whole group would have provided additional useful information. (The objective of the investigation was to determine the Critical Particulate Contaminant and not to perform an extensive statistical analysis that would serve no further purpose. The Critical Particulate Contaminant then would receive further attention.) The selected filters and collected material were digested in nitric acid and analyzed by Inductively Coupled Plasma (ICP) according to NIOSH method 7300 (Schlecht \& O'Connor, 2003). 
Calculations were performed using IHDataAnalyst Lite Version 1.29 (Exposure Assessment Solutions, Inc., Morgantown, WV, www.OESH.com).

Inclusion of metals for further consideration in this investigation reflected their occurrence in the alloys in use as indicated in Table 1, information provided by individual manufacturers for trace quantities, and information provided in the analysis and in Table 2. Elements detected in this analysis above the limit of detection of the analytical method that were not present in the aluminum alloys originated from other sources, including other activities occurring in the shipyard and the surroundings at the time of collection of the air sample.

Excluded from further consideration were metals not identified in composition of the alloys and not having a TLV (potassium, sodium); metals not identified in the alloys and having a very high TLV (molybdenum, tin, tungsten, zirconium); and metals covered under consideration of other metals (calcium, strontium). Silver is known reasonably not to be present in the aluminum alloys under study.

WorkSafeBC, the regulator in British Columbia where this work occurred, requires employers to assess the conditions of work. This assessment required cooperation and active participation from welders and from other workers at the shipyard. Everyone who participated was a volunteer and gave informed consent. Prior to the start, each prospective participant received a brief explanation about what the equipment did and what information it created and stored. Anyone uncomfortable with participation was excused, no questions asked and without repercussion. No names were recorded to ensure that there was no means to identify participants. This work involved about 20 production welders, 5 tackers and 5 fitters, the laborer who managed portable ventilation equipment, and two supervisors. Individual participation varied considerably from one session to multiple sessions depending on comfort in wearing the sampling equipment, interest in the project, and the type of work that was occurring. Monitoring attempted to obtain samples from all relevant types of activity during production welding.

Sampling was spread among the group of workers over the duration of the sample period which spanned several weeks. Sampling was dictated in part by availability of work in specific structures and different geometric configurations as indicated in the results. The realities intrinsic to this situation introduced considerable randomness because the schedule of work was not known in advance of seeking volunteers for a particular day. Driving sample collection were the need to obtain as many samples as possible within the limited time available and a schedule that changed from day to day.

\section{Results}

The structures fabricated in this shipyard necessitated welding in different orientations, downward onto lower horizontal surfaces, upward and downward and side to side on vertical surfaces, and upward and side to side on horizontal overhead surfaces. ASME (American Society of Mechanical Engineers has produced a short-form nomenclature to describe these orientations (ASME, 2010).

During welding downward onto horizontal surfaces (1F, 1G, 2F, 2G, 3F, 3G) in the absence of local effective exhaust ventilation, the welding plume moved up the chest and passed around the neck and up the back of the head or remained in front of the welder. During welding on vertical surfaces $(2 \mathrm{~F}, 2 \mathrm{G}, 3 \mathrm{~F}, 3 \mathrm{G})$, the plume moved up the surface in front of the welder. During welding on overhead surfaces $(4 \mathrm{~F}, 4 \mathrm{G})$, the plume moved along the surface and sometimes became trapped by downward protrusions. Overhead surfaces close to the head can entrap the plume and immerse the face of the welder into the plume, thus contributing to exposure to a high concentration for a prolonged period.

Table 4, Table 5, Table 6, and Table 7 present results from air sampling obtained during various work activities. Particulates included welding fume and could have included dust from grinding although the latter was expected to be very limited for reasons explained previous discussion. As also indicated in previous discussion, total particulates where grinding is occurring approximate inhalable particulates produced during welding through application of a conversion factor of 2.5 (Werner et al., 1996; Spear, 2015; Vincent et al., 1997). Application of the factor of 2.5 where only welding and not grinding was believed to be occurring would overestimate exposure by that factor. Total particulates approximate respirable particulates in welding plumes through application of a conversion factor of 1.0. Concentrations were averaged only over the duration of the sample period. Averaging in this manner provides valuable information about the mode of exposure and still enables calculation of time-weighted average concentrations for the actual work shift for compliance purposes. Conversion from actual sample time to 480 min would decrease the calculated exposure. 
Table 4. Total Dust and Fume, Aluminum, Barium and Beryllium

\begin{tabular}{|c|c|c|c|c|c|c|c|c|c|c|}
\hline \multirow[b]{2}{*}{ Location/ Description } & \multirow[b]{2}{*}{$\begin{array}{l}\text { Flow Rate } \\
\mathrm{L} / \mathrm{min}\end{array}$} & \multirow[b]{2}{*}{$\begin{array}{l}\text { Time } \\
\text { min }\end{array}$} & \multicolumn{2}{|c|}{ Total Dust } & \multicolumn{2}{|c|}{ Aluminum } & \multicolumn{2}{|c|}{ Barium } & \multicolumn{2}{|c|}{ Beryllium } \\
\hline & & & $\begin{array}{l}\text { Mass } \\
\mathrm{mg}\end{array}$ & $\begin{array}{l}\text { Conc. } \\
\mathrm{mg} / \mathrm{m}^{3}\end{array}$ & $\begin{array}{l}\text { Mass } \\
\mu \mathrm{g}\end{array}$ & $\begin{array}{l}\text { Conc. } \\
\mu \mathrm{g} / \mathrm{m}^{3}\end{array}$ & $\begin{array}{l}\text { Mass } \\
\mu \mathrm{g}\end{array}$ & $\begin{array}{l}\text { Conc. } \\
\mu \mathrm{g} / \mathrm{m}^{3}\end{array}$ & $\begin{array}{l}\text { Mass } \\
\mu \mathrm{g}\end{array}$ & $\begin{array}{l}\text { Conc. } \\
\mu \mathrm{g} / \mathrm{m}^{3}\end{array}$ \\
\hline \multirow[t]{3}{*}{ Crane operator } & 2.8 & 131 & 0.04 & 0.1 & & & & & & \\
\hline & 2.0 & 360 & 0.46 & 0.6 & & & & & & \\
\hline & 2.0 & 725 & 0.81 & 0.6 & & & & & & \\
\hline \multicolumn{11}{|l|}{ Laborer } \\
\hline clean-up & 2.0 & 158 & 0.20 & 0.6 & & & & & & \\
\hline Ventilation & 2.0 & 284 & 0.81 & 1.4 & & & & & & \\
\hline \multicolumn{11}{|l|}{ Production welder } \\
\hline Inside pontoon, vertical & 2.0 & 153 & 1.20 & 3.9 & & & & & & \\
\hline \multirow[t]{4}{*}{ surfaces } & 2.0 & 190 & 2.49 & 6.6 & & & & & & \\
\hline & 2.0 & 123 & 4.80 & 20 & & & & & & \\
\hline & 2.0 & 366 & 1.18 & 1.6 & & & & & & \\
\hline & 1.9 & 385 & 1.73 & 2.4 & & & & & & \\
\hline overhead work & 2.0 & 134 & 0.73 & 1.9 & & & & & & \\
\hline \multirow[t]{5}{*}{ downward work } & 2.0 & 356 & 2.29 & 3.1 & & & & & & \\
\hline & 2.0 . & 102 & 0.35 & 1.7 & & & & & & \\
\hline & 2.1 & 132 & 0.57 & 2.1 & & & & & & \\
\hline & 2.0 & 389 & 2.23 & 2.9 & 163 & 588 & 8 & 29 & $<0.05$ & $<0.18$ \\
\hline & 2.0 & 320 & 1.49 & 2.4 & & & & & & \\
\hline Compartments of centre & 2.0 & 376 & 1.64 & 2.2 & & & & & & \\
\hline \multirow[t]{7}{*}{ module } & 2.0 & 390 & 0.90 & 1.1 & & & & & & \\
\hline & 2.0 & 302 & 1.00 & 1.7 & & & & & & \\
\hline & 2.0 & 391 & 3.87 & 4.9 & & & & & & \\
\hline & 2.0 & 413 & 3.58 & 4.4 & & & 131 & & $<005$ & \\
\hline & 2.0 & 420 & 2.41 & 2.9 & 907 & 1098 & 13.1 & 16 & $<0.05$ & $<0.06$ \\
\hline & 2.0 & 405 & 2.18 & 2.7 & $\begin{array}{l}944 \\
579\end{array}$ & 1124 & $\begin{array}{l}3.4 \\
17\end{array}$ & 4 & $\begin{array}{l}<0.05 \\
<0.05\end{array}$ & $<0.00$ \\
\hline & 1.9 & 403 & 1.98 & 2.6 & & & & & & \\
\hline \multirow[t]{6}{*}{ Engine bed, vertical work } & 2.0 & 384 & 5.22 & 6.8 & & & & & & \\
\hline & 2.0 & 116 & 0.28 & 1.2 & 1680 & 2188 & 2.2 & 3 & $<0.05$ & $<0.07$ \\
\hline & 2.0 & 383 & 2.40 & 3.2 & & & & & & \\
\hline & 2.0 & 394 & 8.32 & 11 & & & & & & \\
\hline & 2.0 & 380 & 1.59 & 2.1 & 3230 & 4099 & 1.1 & 1 & $<0.05$ & $<0.06$ \\
\hline & 1.9 & 390 & 0.98 & 1.3 & & & & & & \\
\hline \multirow[t]{4}{*}{ Open area, downward work } & 2.0 & 169 & 1.00 & 3.0 & & & & & & \\
\hline & 2.0 & 396 & 3.85 & 4.9 & & & & & & \\
\hline & 2.0 & 355 & 0.80 & 1.1 & & & & & & \\
\hline & 2.0 & 400 & 2.08 & 2.7 & & & & & & \\
\hline \multirow[t]{4}{*}{ Tacking open area } & 2.0 & 400 & 1.99 & 2.5 & & & & & & \\
\hline & 2.0 & 398 & 2.32 & 2.9 & & & & & & \\
\hline & 2.0 & 391 & 1.95 & 2.5 & & & & & & \\
\hline & 2.0 & 401 & 2.62 & 3.3 & & & & & & \\
\hline \multirow[t]{4}{*}{ A2 machine operator } & 2.1 & 176 & 0.84 & 2.3 & & & & & & \\
\hline & 2.0 & 421 & 2.37 & 2.8 & 722 & 857 & 1.9 & 2 & $<0.05$ & $<0.06$ \\
\hline & 2.0 & 260 & 2.37 & 4.6 & 547 & 1051 & 1.3 & 3 & $<0.05$ & $<0.1$ \\
\hline & 2.0 & 358 & 3.40 & 4.7 & 808 & 1128 & 1.9 & 3 & $<0.05$ & $<0.07$ \\
\hline
\end{tabular}

Table 4 presents results from sampling for total particulates plus ICP analysis for aluminum and barium in selected samples. Samples chosen for ICP analysis were presumed a priori at the time of sampling to have heavier loading based on discussion with the welder and appearance of the sample cassette. This judgement was appropriate for all but one of the highest levels of exposure. Table 5, Table 6, and Table 7 used the same format for additional metals. This enabled comparison of results from ICP analysis directly to gravimetric results. This comparison was appropriate because composition of the material on the filter is believed to be consistent from sample to sample based on information provided in Table 3. 
Particulate levels measured during various types of activity ranged from $1.1 \mathrm{mg} / \mathrm{m}^{3}$ to $20 \mathrm{mg} / \mathrm{m}^{3}$ on production welders. Levels measured during tacking and other tasks were correspondingly less. Overlap occurred between groups of samples in different locations and orientations. Geometric mean and geometric standard deviation calculated for production welders, tackers, and the A2 machine operator were $2.86 \mathrm{mg} / \mathrm{m}^{3}$ (gsd $\left.=1.95\right), 2.78$ $\mathrm{mg} / \mathrm{m}^{3}$ (gsd $\left.=1.14\right)$, and $3.45 \mathrm{mg} / \mathrm{m}^{3}$ ( $\left.\mathrm{gsd}=1.44\right)$, respectively.

The concentration of particulates in two samples $\left(11 \mathrm{mg} / \mathrm{m}^{3}\right.$ and $\left.20 \mathrm{mg} / \mathrm{m}^{3}\right)$ was considerably higher than the main group. These samples occurred in enclosed geometries and may have included entrapment of the plume during work overhead and/or grinding. McManus and Haddad (2016) showed that high concentrations of fume are possible during collection for analysis of various forms of chromium under highly enclosed conditions. Concentrations measured in the main group of samples during production welding ranged from $1.1 \mathrm{mg} / \mathrm{m}^{3}$ to 6.8 $\mathrm{mg} / \mathrm{m}^{3}$. Fitting and tacking and operation of the A2 machine produced exposures within this group of concentrations.

No particular activity directly involved with fabrication consistently produced higher levels of exposure to airborne particulates. Particulate levels during support activity including operation of the overhead crane, clean-up, and provision of ventilation ranged from 0.1 to $1.4 \mathrm{mg} / \mathrm{m}^{3}$. The main criterion governing exposure was proximity to the welding plume and related activities such as metal machining.

The concentration of aluminum in samples submitted for ICP analysis ranged from $599 \mu \mathrm{g} / \mathrm{m}^{3}$ to $4080 \mu \mathrm{g} / \mathrm{m}^{3}$ during tacking and production welding. Several of the samples exceeded the TLV-TWA of $1000 \mu \mathrm{g} / \mathrm{m}^{3}$ for respirable particulates $(\mathrm{ACGIH}, 2018)$ calculated from total particulates through application of the conversion factor for welding of 1.0 (Werner et al., 1996; Spear, 2015; Vincent et al., 1997) during the duration of the sample. The concentration of aluminum in the sample containing the highest level of dust is expected to be considerably higher than $4080 \mu \mathrm{g} / \mathrm{m}^{3}$ and possibly twice this value. That is, if all of the aluminum on the filters arose from respirable particles, the levels would represent an overexposure of an unprotected worker. This is a conservative view of the situation.

One way to investigate the origin of the aluminium measured in these samples is to consider the ratio of the concentration aluminium to total particulates. These values ranged from 240 to $388\left(\mu \mathrm{g} / \mathrm{m}^{3}\right.$ of Al $\left.)\right) /\left(\mathrm{mg} / \mathrm{m}^{3}\right.$ of total particulate). About 5 of the 9 values were in the range from 228 to $280 \mu \mathrm{g} / \mathrm{m}^{3}$ of Al. The upper values suggest the presence of a second source of airborne particulates containing aluminium in the air of the workspace.

Manufacturers of grinding disks indicate that these products typically contain $60 \%$ to $80 \%$ aluminum oxide. (Aluminum oxide is an excellent abrasive.) The remainder of the disk is the binding and support material. This would suggest that aluminum or aluminum oxide should constitute a proportion of the material collected from airborne grinding dust. One unit of aluminum oxide $\left(\mathrm{Al}_{2} \mathrm{O}_{3}\right)$ weighs 3.8 times as much as a unit of aluminum metal (Al). That is, for every atom of aluminum on the filter arising from metallic aluminum in grinding dust, the corresponding atom in aluminum oxide from the welding plume and the grinding wheels weighs 1.9 times as much The presence of aluminum oxide from two possible sources prevents further consideration about any relationship between the weight of dust on the filters and the weight of aluminum determined by ICP analysis.

The previous example demonstrates that assessment of exposure to metals in particulates generated during work of this type is complicated because each of the activities involved in fabrication generates airborne particulates. At the same time, welders are also involved in the associated metalworking activities or work in close proximity to them. Hence, understanding the global nature of the operation is essential for developing reasonable strategies for assessment of exposure.

Levels of barium in samples submitted for ICP analysis ranged from $1 \mu \mathrm{g} / \mathrm{m}^{3}$ to $29 \mu \mathrm{g} / \mathrm{m}^{3}$, very small compared to the TLV-TWA of $500 \mu \mathrm{g} / \mathrm{m}^{3}$ (ACGIH, 2018). Barium was not identified as a component in the aluminum alloys in use here. Overexposure to barium was unlikely to occur during this work.

Beryllium was not detectable in any of the samples submitted for ICP analysis, despite the fact that beryllium is a possible component in some alloys and an element accompanying major elements in others (9-14) (Altenpohl, 1982; Davis, 1993; Frede, 2010; Hashiguchi et al., 2018; Hatch, 1984; Mondalfo, 1976). The actual quantity of beryllium on the filters was somewhere between zero and the Level of Quantitation of $0.05 \mu \mathrm{g}$ (Schlecht \& O'Connor, 2003). Using this level of quantification and a concentration of $1 \mu \mathrm{g} / \mathrm{g}$ (1 part per million) which is in the normal range for beryllium in the environment (Shacklette \& Boerngen, 1981), quantitation in welding plumes is possible using the technique described in McManus and Haddad (2016). 
Table 5. Air Sampling Results for Cadmium, Calcium, Chromium, and Cobalt

\begin{tabular}{|c|c|c|c|c|c|c|c|c|c|c|}
\hline \multirow[b]{2}{*}{ Location/ Description } & \multirow[b]{2}{*}{$\begin{array}{l}\text { Flow Rate } \\
\mathrm{L} / \mathrm{min}\end{array}$} & \multirow[b]{2}{*}{$\begin{array}{l}\text { Time } \\
\text { min }\end{array}$} & \multicolumn{2}{|c|}{ Cadmium } & \multicolumn{2}{|c|}{ Calcium } & \multicolumn{2}{|c|}{ Chromium } & \multicolumn{2}{|l|}{ Cobalt } \\
\hline & & & $\begin{array}{l}\text { Mass } \\
\mu \mathrm{g}\end{array}$ & $\begin{array}{l}\text { Conc. } \\
\mu \mathrm{g} / \mathrm{m}^{3}\end{array}$ & $\begin{array}{l}\text { Mass } \\
\mu \mathrm{g}\end{array}$ & $\begin{array}{l}\text { Conc. } \\
\mu \mathrm{g} / \mathrm{m}^{3}\end{array}$ & $\begin{array}{l}\text { Mass } \\
\mu \mathrm{g}\end{array}$ & $\begin{array}{l}\text { Conc. } \\
\mu \mathrm{g} / \mathrm{m}^{3}\end{array}$ & $\begin{array}{l}\text { Mass } \\
\mu \mathrm{g}\end{array}$ & $\begin{array}{l}\text { Conc. } \\
\mu \mathrm{g} / \mathrm{m}^{3}\end{array}$ \\
\hline \multirow[t]{3}{*}{ Crane operator } & 2.8 & 131 & & & & & & & & \\
\hline & 2.0 & 360 & & & & & & & & \\
\hline & 2.0 & 725 & & & & & & & & \\
\hline \multicolumn{11}{|l|}{ Laborer } \\
\hline clean-up & 2.0 & 158 & & & & & & & & \\
\hline ventilation & 2.0 & 284 & & & & & & & & \\
\hline \multicolumn{11}{|l|}{ Production welder } \\
\hline Inside pontoon, vertical & 2.0 & 153 & & & & & & & & \\
\hline \multirow[t]{4}{*}{ surfaces } & 2.0 & 190 & & & & & & & & \\
\hline & 2.0 & 123 & & & & & & & & \\
\hline & 2.0 & 366 & & & & & & & & \\
\hline & 1.9 & 385 & & & & & & & & \\
\hline overhead work & 2.0 & 134 & & & & & & & & \\
\hline \multirow[t]{5}{*}{ downward work } & 2.0 & 356 & & & & & & & & \\
\hline & 2.0 . & 102 & & & & & & & & \\
\hline & 2.1 & 132 & & & & & & & & \\
\hline & 2.0 & 389 & $<0.01$ & $<0.04$ & 23.8 & 86 & 2 & 7 & $<0.05$ & $<0.2$ \\
\hline & 2.0 & 320 & & & & & & & & \\
\hline Compartments of centre & 2.0 & 376 & & & & & & & & \\
\hline \multirow[t]{7}{*}{ module } & 2.0 & 390 & & & & & & & & \\
\hline & 2.0 & 302 & & & & & & & & \\
\hline & 2.0 & 391 & & & & & & & & \\
\hline & 2.0 & 413 & 0.03 & 0.04 & 34.9 & 42 & 2.1 & 3 & $<0.05$ & $<0.06$ \\
\hline & 2.0 & 420 & 0.03 & 0.04 & 30.3 & 36 & 10.1 & 12 & $<0.05$ & $<0.06$ \\
\hline & 2.0 & 405 & 0.03 & 0.04 & 43.2 & 53 & 3.6 & 4 & 0.6 & 0.7 \\
\hline & 1.9 & 403 & & & & & & & & \\
\hline \multirow[t]{6}{*}{ Engine bed, vertical work } & 2.0 & 384 & $<0.02$ & $<0.03$ & 42.0 & 55 & 5.3 & 7 & $<0.05$ & $<0.07$ \\
\hline & 2.0 & 116 & & & & & & & & \\
\hline & 2.0 & 383 & & & & & & & & \\
\hline & 2.0 & 394 & $<0.01$ & $<0.01$ & 37.6 & 48 & 22.9 & 29 & $<0.05$ & $<0.06$ \\
\hline & 2.0 & 380 & & & & & & & & \\
\hline & 1.9 & 390 & & & & & & & & \\
\hline \multirow[t]{4}{*}{ Open area, downward work } & 2.0 & 169 & & & & & & & & \\
\hline & 2.0 & 396 & & & & & & & & \\
\hline & 2.0 & 355 & & & & & & & & \\
\hline & 2.0 & 400 & & & & & & & & \\
\hline \multirow[t]{4}{*}{ Tacking open area } & 2.0 & 400 & & & & & & & & \\
\hline & 2.0 & 398 & & & & & & & & \\
\hline & 2.0 & 391 & & & & & & & & \\
\hline & 2.0 & 401 & & & & & & & & \\
\hline \multirow[t]{4}{*}{ A2 machine operator } & 2.1 & 176 & & & & & & & & \\
\hline & 2.0 & 421 & $<0.01$ & $<0.01$ & 48.2 & 57 & 13.6 & 16 & $<0.05$ & $<0.06$ \\
\hline & 2.0 & 260 & 0.04 & 0.08 & 43.1 & 83 & 9.2 & 18 & 0.16 & 0.3 \\
\hline & 2.0 & 358 & 0.06 & $<0.08$ & 29.8 & 42 & 45.5 & 64 & 0.27 & 0.4 \\
\hline
\end{tabular}

Using the Level of Quantitation of $0.05 \mu \mathrm{g}$ as the basis for calculation, the concentration of beryllium in samples submitted for ICP analysis ranged from $<0.06 \mu \mathrm{g} / \mathrm{m}^{3}$ to $<0.18 \mu \mathrm{g} / \mathrm{m}^{3}$ during the period of measurement. All of these values potentially exceeded the TLV-TWA of $0.05 \mu \mathrm{g} / \mathrm{m}^{3}$ (inhalable). Some had the potential to exceed the OSHA limit of $0.2 \mu \mathrm{g} / \mathrm{m}^{3}$ during the duration of the samples (ACGIH, 2018; OSHA, 2018). The inhalable and total concentrations would be the same provided that all particles were respirable (originating during welding). Under these conditions, assessing the full potential for overexposure to beryllium was not possible because of insufficient 
material. Further elucidation of exposure requires collection and analysis of a considerably larger quantity of welding fume or aluminum alloy. This question has important implications for the welding industry. OSHA indicated its belief that about 35,000 workers in the US are exposed to beryllium (OSHA, 2018). According to OSHA, exposure occurs when beryllium and beryllium-containing alloys are processed in a way that releases beryllium dust, fume, mist or other form into the workplace air.

Table 5 provides results from air sampling for cadmium, calcium, chromium, cobalt, copper and iron. The concentration of cadmium in samples submitted for ICP analysis ranged from $<0.01 \mu \mathrm{g} / \mathrm{m}^{3}$ to $0.08 \mu \mathrm{g} / \mathrm{m}^{3}$, considerably less than the TLV-TWA of $2 \mu \mathrm{g} / \mathrm{m}^{3}$ for respirable particulates (ACGIH, 2018) calculated from total particulates through application of the conversion factor for welding of 1.0 (Werner et al., 1996; Spear, 2015; Vincent et al., 1997). Cadmium was not identified as a component in the aluminum alloys in use here.

The concentration of calcium in samples submitted for ICP analysis ranged from $36 \mu \mathrm{g} / \mathrm{m}^{3}$ to $86 \mu \mathrm{g} / \mathrm{m}^{3}$, considerably less than the TLV-TWA of $2000 \mu \mathrm{g} / \mathrm{m}^{3}$ for calcium oxide (ACGIH, 2018). Calcium was not identified as a component in the aluminum alloys in use here.

The concentration of total chromium in samples submitted for ICP analysis ranged from $3 \mu \mathrm{g} / \mathrm{m}^{3}$ to $64 \mu \mathrm{g} / \mathrm{m}^{3}$. Chromium is a minor additive in aluminum alloys. Assessment of exposure to chromium solely by this methodology is not possible. Chromium in airborne particulates can exist in multiple forms namely $\operatorname{Cr}(0)$ in aluminum dust, $\mathrm{Cr}(\mathrm{III})$ compounds, soluble $\mathrm{Cr}(\mathrm{VI})$ compounds, insoluble $\mathrm{Cr}(\mathrm{VI})$ compounds and specific chromates. Chromates are Cr(VI) compounds (ACGIH, 2001). Zinc chromate can form from chromium and zinc, both of which are present in the aluminum alloy. Formation of other chromates (calcium chromate, unspecified water soluble and unspecified insoluble chromates, lead chromate and strontium chromate) is possible when the appropriate elements are present.

A companion report (McManus \& Haddad, 2016) examined potential exposure to different forms of chromium during welding of long seams using the A2 machine mentioned earlier. Results are mentioned here because of their importance in this discussion. For the ratio of soluble $\mathrm{Cr}(\mathrm{VI})$ compounds to total $\mathrm{Cr}$, the geometric mean ratio was 0.072 ( $\mathrm{gsd}=1.38$ ). For insoluble $\mathrm{Cr}(\mathrm{VI})$ compounds to total $\mathrm{Cr}$, respectively, the geometric mean ratio was 0.245 (gsd $=1.26)$. The results obtained in this study suggest that soluble $\mathrm{Cr}(\mathrm{VI})$ would be 0.072 or $7.2 \%$ of total chromium. Insoluble $\mathrm{Cr}(\mathrm{VI})$ would be 0.245 or $24.5 \%$ of total $\mathrm{Cr}$. The remainder, 0.683 or $68.3 \%$ would be other forms of chromium.

Using the maximum measured concentration of total $\mathrm{Cr}$ of $64 \mu \mathrm{g} / \mathrm{m}^{3}$, the maximum concentration of soluble $\mathrm{Cr}(\mathrm{VI})$ to which exposure could have occurred would have been $0.072 \times 64 \mu \mathrm{g} / \mathrm{m}^{3}=4.6 \mu \mathrm{g} / \mathrm{m}^{3}$ (McManus \& Haddad, 2016). This concentration is slightly less than the OSHA regulatory Exposure Limit of $5 \mu \mathrm{g} / \mathrm{m}^{3}$ (OSHA, 2015) and less than the TLV of $25 \mu \mathrm{g} / \mathrm{m}^{3}$ for inhalable unspecified, water soluble $\mathrm{Cr}(\mathrm{VI})$ compounds (ACGIH, 2001; ACGIH, 2018). This result was calculated from total particulates in the welding plume through application of the conversion factor for welding of 1.0 (Werner et al., 1996; Spear, 2015; Vincent et al., 1997). Similarly, the concentration of unspecified, insoluble $\mathrm{Cr}(\mathrm{VI})$ would be $0.245 \times 64 \mu \mathrm{g} / \mathrm{m}^{3}=16 \mu \mathrm{g} / \mathrm{m}^{3}$. This concentration is considerably greater than the OSHA regulatory limit of $5 \mu \mathrm{g} / \mathrm{m}^{3}$ for Cr(VI) compounds (OSHA, 2015) and greater than the TLV of $10 \mu \mathrm{g} / \mathrm{m}^{3}$ (ACGIH, 2018) calculated from total particulates through application of the conversion factor for welding of 1.0 (Werner et al., 1996; Spear, 2015; Vincent et al., 1997) for unspecified, inhalable, insoluble $\mathrm{Cr}(\mathrm{VI})$ compounds that could occur in the welding plume (McManus \& Haddad, 2016). When averaged over 8 hours for compliance purposes, the average concentration would decrease.

OSHA (2015) in the US combined all forms of $\mathrm{Cr}(\mathrm{VI})$, that is, both water soluble and water insoluble. The level of exposure derived here could necessitate control measures such as specially designed exhaust systems or other means of ventilation despite the short duration of actual welding during the day. Further exploratory sampling could determine whether the maximum measured level used in the calculations was appropriate or an extreme that does not occur in other situations. The impact of this result for jurisdictions regulated through use of the TLV as the Exposure Limit and especially TLV + ALARA (As Low As Reasonably Achievable), is the same namely that control measures are necessary despite the small quantity of $\mathrm{Cr}$ in aluminum alloys.

For other forms of $\mathrm{Cr}$, the maximum concentration would be $0.683 \times 64 \mu \mathrm{g} / \mathrm{m}^{3}=44 \mu \mathrm{g} / \mathrm{m}^{3}$ for $\mathrm{Cr}(0)+\mathrm{Cr}(\mathrm{III})$ (McManus \& Haddad, 2016). This concentration is considerably less than the 8-hour TLV of $500 \mu \mathrm{g} / \mathrm{m}^{3}$ (ACGIH, 2018). 
Table 6. Air Samples for Copper, Iron, Lead, and Magnesium

\begin{tabular}{|c|c|c|c|c|c|c|c|c|c|c|}
\hline \multirow[b]{2}{*}{ Location/ Description } & \multirow[b]{2}{*}{$\begin{array}{l}\text { Flow Rate } \\
\mathrm{L} / \mathrm{min}\end{array}$} & \multirow[b]{2}{*}{$\begin{array}{l}\text { Time } \\
\min \end{array}$} & \multicolumn{2}{|c|}{ Copper } & \multicolumn{2}{|l|}{ Iron } & \multicolumn{2}{|l|}{ Lead } & \multicolumn{2}{|c|}{ Magnesium } \\
\hline & & & $\begin{array}{l}\text { Mass } \\
\mu \mathrm{g}\end{array}$ & $\begin{array}{l}\text { Conc. } \\
\mu \mathrm{g} / \mathrm{m}^{3}\end{array}$ & $\begin{array}{l}\text { Mass } \\
\mu \mathrm{g}\end{array}$ & $\begin{array}{l}\text { Conc. } \\
\mu \mathrm{g} / \mathrm{m}^{3}\end{array}$ & $\begin{array}{l}\text { Mass } \\
\mu \mathrm{g}\end{array}$ & $\begin{array}{l}\text { Conc. } \\
\mu \mathrm{g} / \mathrm{m}^{3}\end{array}$ & $\begin{array}{l}\text { Mass } \\
\mu \mathrm{g} \\
\end{array}$ & $\begin{array}{l}\text { Conc. } \\
\mu \mathrm{g} / \mathrm{m}^{3}\end{array}$ \\
\hline \multirow[t]{3}{*}{ Crane operator } & 2.8 & 131 & & & & & & & & \\
\hline & 2.0 & 360 & & & & & & & & \\
\hline & 2.0 & 725 & & & & & & & & \\
\hline \multicolumn{11}{|l|}{ Laborer } \\
\hline clean-up & 2.0 & 158 & & & & & & & & \\
\hline Ventilation & 2.0 & 284 & & & & & & & & \\
\hline \multicolumn{11}{|l|}{ Production welder } \\
\hline Inside pontoon, vertical & 2.0 & 153 & & & & & & & & \\
\hline \multirow[t]{4}{*}{ surfaces } & 2.0 & 190 & & & & & & & & \\
\hline & 2.0 & 123 & & & & & & & & \\
\hline & 2.0 & 366 & & & & & & & & \\
\hline & 1.9 & 385 & & & & & & & & \\
\hline overhead work & 2.0 & 134 & & & & & & & & \\
\hline \multirow[t]{5}{*}{ downward work } & 2.0 & 356 & & & & & & & & \\
\hline & 2.0 . & 102 & & & & & & & & \\
\hline & 2.1 & 132 & & & & & & & & \\
\hline & 2.0 & 389 & 8 & 29 & 24 & 87 & $<0.2$ & $<0.7$ & 25 & 90 \\
\hline & 2.0 & 320 & & & & & & & & \\
\hline Compartments of centre & 2.0 & 376 & & & & & & & & \\
\hline \multirow[t]{7}{*}{ module } & 2.0 & 390 & & & & & & & & \\
\hline & 2.0 & 302 & & & & & & & & \\
\hline & 2.0 & 391 & & & & & & & & \\
\hline & 2.0 & 413 & 13.1 & 16 & 46 & 56 & $<0.2$ & $<0.2$ & 185 & 224 \\
\hline & 2.0 & 420 & 3.4 & 4 & 60 & 71 & $<0.2$ & $<0.2$ & 99 & 118 \\
\hline & 2.0 & 405 & 1.7 & 2 & 60 & 74 & 0.7 & 0.9 & 87 & 107 \\
\hline & 1.9 & 403 & & & & & & & & \\
\hline \multirow[t]{6}{*}{ Engine bed, vertical work } & 2.0 & 384 & 2.2 & 3 & 58 & 76 & 1.3 & 1.7 & 425 & 553 \\
\hline & 2.0 & 116 & & & & & & & & \\
\hline & 2.0 & 383 & & & & & & & & \\
\hline & 2.0 & 394 & 1.1 & 1 & 117 & 148 & 0.5 & 0.6 & 639 & 811 \\
\hline & 2.0 & 380 & & & & & & & & \\
\hline & 1.9 & 390 & & & & & & & & \\
\hline \multirow[t]{4}{*}{ Open area, downward work } & 2.0 & 169 & & & & & & & & \\
\hline & 2.0 & 396 & & & & & & & & \\
\hline & 2.0 & 355 & & & & & & & & \\
\hline & 2.0 & 400 & & & & & & & & \\
\hline \multirow[t]{4}{*}{ Tacking open area } & 2.0 & 400 & & & & & & & & \\
\hline & 2.0 & 398 & & & & & & & & \\
\hline & 2.0 & 391 & & & & & & & & \\
\hline & 2.0 & 401 & & & & & & & & \\
\hline \multirow[t]{4}{*}{ A2 machine operator } & 2.1 & 176 & & & & & & & & \\
\hline & 2.0 & 421 & 1.9 & 2 & 141 & 167 & 0.7 & 0.8 & 128 & 152 \\
\hline & 2.0 & 260 & 1.3 & 3 & 64 & 123 & $<0.2$ & $<0.4$ & 140 & 269 \\
\hline & 2.0 & 358 & 1.9 & 3 & 230 & 321 & 0.6 & 0.8 & 154 & 215 \\
\hline
\end{tabular}

Calcium, sodium and potassium, and lead were detectable in these samples but were not present in the metal. The ability of chromates containing these elements to form in the plume in the absence of these elements as ingredients in the aluminum alloys is not known. Chromates containing these elements usually are encountered in the context of other industrial processes, namely abrasive blasting and painting and coating where these substances are ingredients. These activities were occurring in the area. 
Table 7. Air Samples for manganese, nickel, vanadium and zinc

\begin{tabular}{|c|c|c|c|c|c|c|c|c|c|c|}
\hline \multirow[b]{2}{*}{ Location/ Description } & \multirow[b]{2}{*}{$\begin{array}{l}\text { Flow } \\
\mathrm{L} / \mathrm{min}\end{array}$} & \multirow[b]{2}{*}{$\begin{array}{c}\text { RateTime } \\
\text { min }\end{array}$} & \multicolumn{2}{|c|}{ Manganese } & \multicolumn{2}{|c|}{ Nickel } & \multicolumn{2}{|c|}{ Vanadium } & \multicolumn{2}{|l|}{ Zinc } \\
\hline & & & $\begin{array}{l}\text { Mass } \\
\mu \mathrm{g}\end{array}$ & $\begin{array}{l}\text { Conc. } \\
\mu \mathrm{g} / \mathrm{m}^{3}\end{array}$ & $\begin{array}{l}\text { Mass } \\
\mu \mathrm{g}\end{array}$ & $\begin{array}{l}\text { Conc. } \\
\mu \mathrm{g} / \mathrm{m}^{3}\end{array}$ & $\begin{array}{l}\text { Mass } \\
\mu \mathrm{g}\end{array}$ & $\begin{array}{l}\text { Conc. } \\
\mu \mathrm{g} / \mathrm{m}^{3}\end{array}$ & $\begin{array}{l}\text { Mass } \\
\mu \mathrm{g} \\
\end{array}$ & $\begin{array}{l}\text { Conc. } \\
\mu \mathrm{g} / \mathrm{m}^{3}\end{array}$ \\
\hline \multirow[t]{3}{*}{ Crane operator } & 2.8 & 131 & & & & & & & & \\
\hline & 2.0 & 360 & & & & & & & & \\
\hline & 2.0 & 725 & & & & & & & & \\
\hline \multicolumn{11}{|l|}{ Laborer } \\
\hline clean-up & 2.0 & 158 & & & & & & & & \\
\hline ventilation & 2.0 & 284 & & & & & & & & \\
\hline \multicolumn{11}{|l|}{ Production welder } \\
\hline Inside pontoon, vertical & 2.0 & 153 & & & & & & & & \\
\hline \multirow[t]{4}{*}{ surfaces } & 2.0 & 190 & & & & & & & & \\
\hline & 2.0 & 123 & & & & & & & & \\
\hline & 2.0 & 366 & & & & & & & & \\
\hline & 1.9 & 385 & & & & & & & & \\
\hline overhead work & 2.0 & 134 & & & & & & & & \\
\hline \multirow[t]{5}{*}{ downward work } & 2.0 & 356 & & & & & & & & \\
\hline & 2.0 . & 102 & & & & & & & & \\
\hline & 2.1 & 132 & & & & & & & & \\
\hline & 2.0 & 389 & 1.6 & 6 & 0.4 & 1.4 & $<0.1$ & $<0.4$ & 3.8 & 14 \\
\hline & 2.0 & 320 & & & & & & & & \\
\hline Compartments of centre & 2.0 & 376 & & & & & & & & \\
\hline \multirow[t]{7}{*}{ module } & 2.0 & 390 & & & & & & & & \\
\hline & 2.0 & 302 & & & & & & & & \\
\hline & 2.0 & 391 & & & & & & & & \\
\hline & 2.0 & 413 & 10 & 12 & 0.6 & 0.7 & $<0.1$ & $<0.1$ & 2.9 & 4 \\
\hline & 2.0 & 420 & 9 & 11 & 4.1 & 5 & 0.1 & 0.1 & 2.6 & 3 \\
\hline & 2.0 & 405 & 60 & 74 & 1 & 1.1 & $<0.1$ & $<0.1$ & 1.3 & 2 \\
\hline & 1.9 & 403 & & & & & & & & \\
\hline \multirow[t]{6}{*}{ Engine bed, vertical work } & 2.0 & 384 & 17 & 22 & 1.4 & 2 & 0.2 & 0.3 & 4. & 5 \\
\hline & 2.0 & 116 & & & & & & & & \\
\hline & 2.0 & 383 & & & & & & & & \\
\hline & 2.0 & 394 & 26 & 33 & 10.1 & 13 & 0.3 & 0.4 & 21 & 27 \\
\hline & 2.0 & 380 & & & & & & & & \\
\hline & 1.9 & 390 & & & & & & & & \\
\hline \multirow[t]{4}{*}{ Open area, downward work } & 2.0 & 169 & & & & & & & & \\
\hline & 2.0 & 396 & & & & & & & & \\
\hline & 2.0 & 355 & & & & & & & & \\
\hline & 2.0 & 400 & & & & & & & & \\
\hline \multirow[t]{4}{*}{ Tacking open area } & 2.0 & 400 & & & & & & & & \\
\hline & 2.0 & 398 & & & & & & & & \\
\hline & 2.0 & 391 & & & & & & & & \\
\hline & 2.0 & 401 & & & & & & & & \\
\hline \multirow[t]{4}{*}{ A2 machine operator } & 2.1 & 176 & & & & & & & & \\
\hline & 2.0 & 421 & 8 & 10 & 9.1 & 11 & 0.2 & 0.2 & 6.3 & 7 \\
\hline & 2.0 & 260 & 6 & 12 & 3.7 & 7 & $<0.1$ & $<0.2$ & 9.1 & 18 \\
\hline & 2.0 & 358 & 10 & 14 & 20.5 & 29 & 0.2 & 0.3 & 12.2 & 17 \\
\hline
\end{tabular}

The concentration of cobalt in samples submitted for ICP analysis ranged from $<0.06 \mu \mathrm{g} / \mathrm{m}^{3}$ to $0.7 \mu \mathrm{g} / \mathrm{m}^{3}$, considerably less than the TLV-TWA of $20 \mu \mathrm{g} / \mathrm{m}^{3}$ during the duration of the samples (ACGIH, 2018). Cobalt was not identified as a component in the aluminum alloys in use here. Under these conditions, overexposure to cobalt was highly unlikely to occur.

Table 6 presents results from sampling for copper, iron, lead, and magnesium. The concentration of copper in samples submitted for ICP analysis ranged from $1 \mu \mathrm{g} / \mathrm{m}^{3}$ to $16 \mu \mathrm{g} / \mathrm{m}^{3}$. These concentrations were considerably less 
than the TLV-TWA of $200 \mu \mathrm{g} / \mathrm{m}^{3}$ (ACGIH, 2018). Under these conditions, overexposure to copper was highly unlikely to occur.

The concentration of iron in samples submitted for ICP analysis ranged from $57 \mu \mathrm{g} / \mathrm{m}^{3}$ to $167 \mu \mathrm{g} / \mathrm{m}^{3}$. These concentrations were considerably less than the TLV-TWA of $5000 \mu \mathrm{g} / \mathrm{m}^{3}$ for respirable particulates (ACGIH) calculated from total particulates through application of the conversion factor for welding of 1.0 (Werner et al., 1996; Spear, 2015; Vincent et al., 1997). Under these conditions, overexposure to iron was highly unlikely to occur.

The concentration of lead in samples submitted for ICP analysis ranged from $<0.2 \mu \mathrm{g} / \mathrm{m}^{3}$ to $1.7 \mu \mathrm{g} / \mathrm{m}^{3}$, considerably less than the TLV-TWA of $50 \mu \mathrm{g} / \mathrm{m}^{3}$ (ACGIH, 2018). Lead was not identified as a component in the aluminum alloys in use here. Under these conditions, overexposure to lead was highly unlikely to occur.

The concentration of magnesium in samples submitted for ICP analysis ranged from $92 \mu \mathrm{g} / \mathrm{m}^{3}$ to $808 \mu \mathrm{g} / \mathrm{m}^{3}$. These concentrations were considerably less than the TLV of $10,000 \mu \mathrm{g} / \mathrm{m}^{3}$ (ACGIH, 2018) for inhalable particulates calculated from total particulates through application of the conversion factor for welding of 1.0 (Werner et al., 1996; Spear, 2015; Vincent et al., 1997) and less than the TLV of $3000 \mu \mathrm{g} / \mathrm{m}^{3}$ (ACGIH, 2018) for respirable particulates calculated from total particulates through application of the conversion factor for welding of 1.0 (Werner et al., 1996; Spear, 2015; Vincent et al., 1997). Under these conditions, overexposure to magnesium was highly unlikely to occur.

Table 7 presents results from sampling for manganese, nickel, vanadium, and zinc. The concentration of manganese in samples submitted for ICP analysis ranged from $6 \mu \mathrm{g} / \mathrm{m}^{3}$ to $33 \mu \mathrm{g} / \mathrm{m}^{3}$. Some of these results exceeded the TLV-TWA of $20 \mu \mathrm{g} / \mathrm{m}^{3}$ for respirable particulates (ACGIH, 2018) calculated from total particulates through application of the conversion factor for welding of 1.0 (Werner et al., 1996; Spear, 2015; Vincent et al., 1997). The TLV-TWA of $200 \mu \mathrm{g} / \mathrm{m}^{3}$ for inhalable particulates (ACGIH, 2018) is not applicable since all particles are assumed to be respirable due to source. Under these conditions on a first pass of testing, overexposure of unprotected workers to manganese relative to the TLV-TWA for respirable particulates was likely.

The concentration of nickel in samples submitted for ICP analysis ranged from $0.2 \mu \mathrm{g} / \mathrm{m}^{3}$ to $29 \mu \mathrm{g} / \mathrm{m}^{3}$. These concentrations were less than the TLV-TWA of $200 \mu \mathrm{g} / \mathrm{m}^{3}$ for inhalable particulates (insoluble compounds) (ACGIH, 2018 calculated from total particulates through application of the conversion factor for welding of 1.0 (Werner et al., 1996; Spear, 2015; Vincent et al., 1997). Under these conditions, overexposure of unprotected workers to nickel was unlikely to occur.

The concentration of vanadium in samples submitted for ICP analysis ranged from $<0.1 \mu \mathrm{g} / \mathrm{m}^{3}$ to $0.4 \mu \mathrm{g} / \mathrm{m}^{3}$, considerably less than the TLV-TWA of $50 \mu \mathrm{g} / \mathrm{m}^{3}$ for inhalable particulates (ACGIH, 2017) calculated from total particulates using the conversion factor for welding of 1.0 (Werner et al., 1996; Spear, 2015; Vincent et al., 1997). Vanadium was not identified as a component in the aluminum alloys in use here. Under these conditions, overexposure of unprotected workers to vanadium was highly unlikely to occur.

The concentration of zinc in samples submitted for ICP analysis ranged from $2 \mu \mathrm{g} / \mathrm{m}^{3}$ to $27 \mu \mathrm{g} / \mathrm{m}^{3}$. These concentrations were considerably less than the TLV-TWA of $2000 \mu \mathrm{g} / \mathrm{m}^{3}$ for respirable particulates (ACGIH, 2018) calculated from total particulates through application of the conversion factor for welding of 1.0 (Werner et al., 1996; Spear, 2015; Vincent et al., 1997). On this basis, overexposure of unprotected workers to zinc was unlikely to occur.

\section{Discussion}

This study highlights an important strategy in welding processes, namely to determine the Critical Contaminant. Overexposure to the Critical Contaminant determines the response to regulatory requirements. In complex processes such as welding where many substances are present at different concentrations and have different regulatory Exposure Limits, the Critical Contaminant could be gaseous or particulate. Previous studies in exposure assessment have shown the likely involvement of $\mathrm{NO}_{2}$ as a gaseous Critical Gaseous Contaminant during GTAW (TIG welding) processes (McManus \& Haddad, 2018) and and ozone during GMAW (MIG welding) processes (McManus \& Haddad, 2019b) involving aluminium alloys. Substances in contention for the Critical Particulate Contaminant determined during this investigation include beryllium, $\mathrm{Cr}(\mathrm{VI})$ compounds, and possibly manganese. Both beryllium and CrVI are not detectable in routine air samples. Absence of detectability in context of an extremely small TLV is not proof of absence of concern. Resolving this question requires large quantities of material. This is achievable using techniques of McManus and Haddad (2016).

The methodology employed here depended on the ability to distinguish tasks producing only respirable particulates from those producing a wide range of sizes (welding versus welding + grinding) in order to be able to 
utilize conversion factors (Werner et al., 1996; Spear, 2015; Vincent et al., 1997). Respirable particulates are a fraction of total particulates. Hence, total particulates can substitute for respirable particulates in the case of exposure to welding fume where respirable and total particulates are the same. The only differentiation occurs in the case of grinding where respirable particulates may exist in the dust cloud. In a mixed environment containing both fume and dust and no means to differentiate between them, this situation can create a source of error in exposure estimation. This was particularly apparent with aluminium because of use of aluminium oxide in grinding wheels. As employed in this study, the methodology appears to have been acceptable in identifying contenders for the Critical Particulate Contaminant.

Potential or real overexposure to Critical Contaminants focuses attention onto control measures needed to obtain compliance. Control measures for Critical Gaseous Contaminants could differ from those for Critical Particulate contaminants. This is most obvious where reliance on respiratory protection (air-purifying versus air-supplying) must occur. Air-supplying respirators require considerably greater infrastructure. The substance that dominates the concern will dictate whether control measures other than personal protective equipment are technically possible. Measures to control welding emissions usually include local exhaust ventilation systems portable or installed.

Workers participating in this study routinely chose to use half- or full-facepiece air-purifying respirators as the first line of defence against exposure to the substances in welding plumes. The facility also contained an installed High Velocity, Low Volume (HVLV) local exhaust system. This situation illustrates the importance of determining the Critical Contaminant and related considerations in advance of making decisions about implementation of control measures to obtain regulatory compliance.

Exclusive use of respirators allowed the welding plume to rise to the roof space of the Fabrication Building. Roof-level exhaust fans transferred much of the particulate matter to the external atmosphere. Some of the particulate material deposited surfaces of girders, the bridge crane and other horizontal surfaces in the upper part of the building. At some point in the history of the operation, cleaning of these surfaces becomes necessary because of falling debris and contamination of surfaces at the level of work. Cleaning is a difficult process partly because of the height and partly because of loose material containing fine, readily aerosolized particles.

The HVLV system was similar in concept to a vacuum cleaner. Hoses connected collector hoods during use to a central large-diameter pipe. Connection to the system created an instantaneous high velocity in the hose. At the same time, the velocity in the large diameter collector pipe decreased. Connection of multiple hoses led to decrease sufficient for deposition of material onto the interior of the collector pipe due to insufficient air velocity.

Welders did not use this system during this work or did not use it effectively. Any exhaust system installed to control exposure to emissions from argon-shielded GMAW (MIG welding) on aluminum alloys must address several realities in order to gain acceptance and use. The first is containment of emissions. Containment of emissions requires usability and effective collection. In order to effectively collect and remove the hot plume, positioning the collector above and in front of and away from the face is essential.

The HVLV system was almost impossible to use for several reasons. The first reason was the inability of welders to position the collector hood appropriately. This was a consequence of inability to see the plume through the dark lens used for viewing the arc and the constantly changing geometry of the weld. Effective positioning to collect the plume required involvement of a worker dedicated specifically to this task. Positioning the collector hood was also highly problematic because the irregular geometry of the structure and the nonferrous nature of aluminum precluded magnetic attachment of holding devices onto surfaces. The considerable variety of geometric configurations required many configurations of the clamping mechanisms, an additional reason for the necessary involvement of a worker dedicated to this task.

The second reason was interference with weld quality. This occurred because of disruption or destruction of the gaseous shield. Requirements for control of worker exposure conflicted with requirements for weld quality. Weld quality motivates all actions of welders. Maintaining the integrity of the gaseous shield around the arc was essential for obtaining welds meeting requirements for quality. Turbulence induced by entrainment of air into the collector hood can destroy the shield formed by the argon. Positioning the collector in a location to collect the plume but not to destroy the shield is an acquired skill requiring intuition and attention to detail. The many variations in geometry and position and inability to position collector hoods in the appropriate position overcame attempts by even the most determined and dedicated individuals to use this equipment in a manner consistent with satisfying the two conflicting requirements. 


\section{Conclusions}

The traditional method of sampling for welding fume using closed face cassettes and gravimetric and ICP analysis continues to offer utility for first-level assessment of emissions from aluminum alloys during argon-shielded GMAW (MIG welding) processes. Application of this approach requires an environment involving exposure only to welding fume and use of a conversion factor for metals possessing TLVs based on respirable and inhalable particulates (Werner et al., 1996; Spear, 2015; Vincent et al., 1997). This approach also can accommodate grinding and dusty work occurring separately from welding. Where grinding and welding occur simultaneously, this approach may not provide satisfactory interpretation of the data because of the presence of respirable and larger particles in the same sample. This approach causes greatest difficulty for interpretation of exposure to manganese. Manganese simultaneously possesses TLVs for inhalable particulates and respirable particulates. This situation has not changed with introduction of TLVs for inhalable particulates.

The Critical Contaminant is an important concept in creating a strategy for assessing exposure in complex environments. A process can have simultaneous Critical Gaseous and Particulate Contaminants. One contaminant likely will dominate in a situation. Overexposure to the Critical Component determines the type and extent of control needed to achieve regulatory compliance. Determination of the Critical Component requires air- and sometimes bulk-sampling of particulates. Sampling offers a quantitative way to differentiate importance between large quantities of substance having a high regulatory Exposure Limit and small or even undetectable quantities having a very small regulatory Exposure Limit.

Beryllium and chromium VI are likely Critical Particulate Contaminants during argon-shielded GMAW (MIG welding) processes on aluminium alloys. Manganese is a possible Critical Particulate Contaminant. Determination and assessment of exposure to beryllium and chromium VI require advanced strategies because of limitations of detection. As particulate Critical Particulate Contaminants, these elements likely will dominate discussion and imposition of control measures during this type of welding. If this is the case, discussion about application of conversion factors to correct TLVs to assess exposure to respirable and inhalable versus total particulates becomes moot.

\section{Acknowledgments}

Thomas Neil McManus received a scholarship from CAPES (Coordenação de Aperfeiçoamento de Pessoal de Nível Superior), Brasilia, DF, Brasil. Assed Haddad received a grant from CNPq (Conselho Nacional de Desenvolvimento Científico e Tecnológico), formerly Conselho Nacional de Pesquisas, Brasilia, DF, Brasil (the Brazililian National Research Council) in pursuit of this work are gratefully acknowledged.

\section{Conflict of interests}

The authors declare that there is no conflict of interests regarding the publication of this paper.

\section{References}

ACGIH (American Conference of Governmental Industrial Hygienists). (2001). Chromium metal and inorganic compounds. In Documentation of the TLVS and BEIs. Cincinnati, OH: American Conference of Governmental Industrial Hygienists. [CD-ROM].

ACGIH (American Conference of Governmental Industrial Hygienists). (2018). Threshold Limit Values for Chemical Substances and Physical Agents \& Biological Exposure Indices. Cincinnati, OH: American Conference of Governmental Industrial Hygienists.

Altenpohl, D. (1982). Aluminum viewed from within. Düsseldorf: Aluminum-Verlag.

Armbruster, D. A., \& Pry, T. L. (2008). Limit of blank, limit of detection and limit of quantitation. Clinical Biochemistry Reviews, 29(Supplement (i) August), S49-S52.

ASME (American Society of Mechanical Engineers). (2010). ASME boiler and pressure vessel code. IX Operators. New York, NY: American Society of Mechanical Engineers.

CSA (Canadian Standards Association) Group. (2011). Certification of companies for fusion welding of aluminum (CAN/CSA W47.2-11). CSA Group: Mississauga, ON.

Davis, J. R. (Ed.) (1993). Aluminum and aluminum alloys. Materials Park, OH: American Society for Materials International.

Frede, W. (2010). Beryllium in A357 castings. Lawrence Livermore National Laboratory, Beryllium Health \& Safety Committee Meeting, Washington, DC, March, 2010. Retrieved from https://bhsc.llnl.gov/documents/03_10_BHSC_Meeting/3-17-10C-Frede.pdf 
Goller, J. W., \& Paik, N. W. (1985). A comparison of iron oxide fume inside and outside of welding helmets. American Industrial Hygiene Association Journal, 46, 89-93

Hashiguchi, D., Ashurst, A. N., Grensing, F. C., \& Marder, J. M. (2018). Aluminum-beryllium alloys for aerospace applications. Retrieved from https:/materion.com/ /media/Files/PDFs/Beryllium $/$ AlBeMet $\%$ 20Materials/MAAB-015AluminiumBerylliumAlloysforAerospaceApplications.pdf

Hatch, J. E. (1984). Aluminum: Properties and physical metallurgy. Materials Park, OH: American Society for Materials International.

Jahn, S. D., Bullock, W. H., \& Ignacio, J. (Eds.) (2015). A Strategy for assessing and managing occupational exposures (4th ed.). Falls Church, VA: American Industrial Hygiene Association.

McKinlay, A. (1992). Optical radiation. In Non-ionizing radiation. Proceedings of the 2nd International Non-Ionizing Radiation Workshop, Vancouver, British Columbia, Canada, 1992 May 10-14, M. W. Greene (Ed.). London: International Radiation Protection Association, The Institution of Nuclear Engineers.

McManus, N., \& Haddad, A. N. (2015a). Argon-related fatigue: An investigation in an aluminum shipbuilding environment. Professional Safety, 60(10), 47-55.

McManus, N., \& Haddad, A. N. (2015b). Oxygen levels during welding assessment in an aluminum shipbuilding environment. Professional Safety, 60(7), 26-32.

McManus, T. N., \& Haddad, A. N. (2013). UV and blue light exposures in an aluminum shipbuilding environment. International Journal of Open Scientific Research, 1(6), 15-27.

McManus, T. N., \& Haddad, A. N. (2014). Use of methanol as a coolant during machining of aluminum in a shipbuilding environment: A failure to assess and manage risk. Advanced Materials Research, 955-959, 1061-1064.

McManus, T. N., \& Haddad, A. N. (2016). Chromium emissions during welding in an aluminum shipbuilding environment. Welding Journal, 95(03), 86-s-92-s.

McManus, T. N., \& Haddad, A. N. (2018). Welder exposure to $\mathrm{NO}$ and $\mathrm{NO}_{2}$ during argon-shielded arc welding on aluminum alloys. Toxicology and Environmental Health Sciences, 10(5), 297-306.

McManus, T. N., \& Haddad, A. N. (2019a). Assessment of technologies for measuring exposure to $\mathrm{NO}_{2}$ during welding on aluminum alloys. Environment and Natural Resources Research, 9(2), 75-85.

McManus, T. N., \& Haddad, A. N. (2019b). Ozone: A critical contaminant produced during gas metal arc welding (GMAW) on aluminum alloys - resolving the short- versus long-duration sampling discrepancy. Air Quality, Atmosphere and Health, 12, 97-106(2019).

McManus, T. N., \& Haddad, A. N. (2020). Assessment, selection and demonstration of technologies and equipment for measuring welder exposure to ozone during GMAW (MIG Welding) on aluminum alloys. Environment and Natural Resources Research, 10(1), 14-27.

Mondalfo, L. F. (1976). Aluminum alloys, structure and properties. London: Butterworths.

NIOSH (National Institute for Occupational Safety and Health). (1988). Criteria for a recommended standard, welding, brazing, and thermal cutting, Publication No. 88-110. Cincinnati, OH: Department of Health and Human Services, Public Health Service (US), Centers for Disease Control, National Institute for Occupational Safety and Health. DHHS (NIOSH).

OSHA (Occupational Safety and Health Administration). (2015). Chromium (VI) (29CFR 1910.1026). Washington, DC: US Department of Labor, Occupational Safety Administration. Retrieved from https://www.osha.gov/pls/oshaweb/owadisp.show_document?p_table=STANDARDS\&p_id=1309610

OSHA (Occupational Safety and Health Administration). (2018). Beryllium (29CFR1910.1024). Washington, DC: US Department of Labor, Occupational Safety and Health Administration. Retrieved from https:/www.osha.gov/pls/oshaweb/owadisp.show_document?p_table=STANDARDS\&p_id=1309

Schlecht, P. C., \& O'Connor, P. F. (2003). NIOSH manual of analytical methods (NMAM7) (4th ed., 3rd Suppl.). DHHS (NIOSH) Publication 94-113 (August, 1994), 1st Supplement Publication 96-135, 2nd Supplement Publication 98-119, 3rd Supplement 2003-154. Cincinnati, OH: Department of Health and Human Services (US), Centers for Disease Control and Prevention, National Institute for Occupational Safety and Health.

Shacklette, H. T., \& Boerngen, J. C. (1981). Chemical analysis of soils and other surficial materials of the conterminous United States. Open-File Report, 81-197. Denver, CO: U.S. Geological Survey. 
SKC, Inc. (2018). Size-selective sampling of particulate matter for occupational hygiene. Eighty-four, PA: SKC Inc. Retrieved from http://www.skcinc.com/catalog/infopage.php?id=9020

Spear, J. (2015). The viability of particle size-selective exposure assessments for welding and allied processes. Presentation at the American Industrial Hygiene Conference and Exhibition, AIHCE 2015, Salt Lake City, UT, June, 2015.

Swint, W. (2015). Parameters employed during welding on aluminum during construction of the PacifiCats. Victoria, BC, Canada: March 11, 2015. [personal communication].

Vincent, J. H., Brosseau, L. M., Ramachandran, G., Perng-Jy Tsai, T., Spear, J. M., Werner, M. A., \& McCullough, N. V. (1997). Current issues in exposure assessment for workplace aerosols. Annals of Occupational Hygiene, 41(Supplement 1), 607-614.

Werner, M. A., Spear, J. E., \& Vincent, J. H. (1996). Investigation into the impact of introducing workplace aerosol standards based on the inhalable fraction. Analyst, 121, 1207-121.

\section{Copyrights}

Copyright for this article is retained by the author(s), with first publication rights granted to the journal.

This is an open-access article distributed under the terms and conditions of the Creative Commons Attribution license (http://creativecommons.org/licenses/by/4.0/). 